\title{
Improve the quality of English Cake by using of some Enzymes
}

\author{
Al-Refia Y.A. ${ }^{1,2}$, Sharoba A.M. ${ }^{1}$ and Morsy M.K. ${ }^{1}$ \\ ${ }^{l}$ Department of Food Technology, Faculty of Agriculture, Benha University, Qaluobia, Egypt. \\ ${ }^{2}$ Department of Food Science and Biotechnology, Faculty of Agriculture, Tikrit University, Salah El-Deen, Iraq
}

Corresponding author: ashraf_sharoba@yahoo.com

\begin{abstract}
Bakeries occupy an important position in human nutrition locally and globally. Given the gap between production and consumption, governments are importing wheat from different countries. Ukrainian wheat is therefore the most widely used wheat in Egypt and Iraq. In order to match their characteristics with the local concessions, whether Egyptian or Iraqi.The study investigated the use of Ukrainian wheat in the production of $72 \%$ flour for the manufacture of English cake. The study also included the evaluation of some enzyme enhancers, which included $\alpha$-amylase $(0.3 \%)$ and glucose oxidase $(0.1 \%)$. The study also examined the characteristics of the English cake in terms of (chemical composition, gluten, rheology, textures, staling, microbiology, sensory) during the storage period of 12 days at $25 \pm 1{ }^{\circ} \mathrm{C}$. The results showed a clear and noticeable improvement of all technological characteristics under study, the most important of which was the increase of the validity period to reach 12 days for the English cake compared to the sample (control). Therefore, the study recommends the use of the following $\alpha$-amylase, commercial glucose oxidase in the manufacture of some bakery products.
\end{abstract}

Key words: Ukrainian wheat, $\alpha$ - amylase, Rheological, chemical composition; microbiological examination, English cake.

\section{Introduction}

Cakes are the most consumed bakery product attributable to interesting items and are constantly utilized as a part of celebrations and also in happy festivals (Hafez, A.A. 2012; Zhang, Y., et al. 2012) .

Bakery products are extensively consumed and therefore particular requirements for their quality characteristics have been established. Especially for cake, shape, color and texture are important for consumers. Shelf-life of bakery products is mainly limited by staling. Staling is a process of chemical and physical changes including moisture redistribution, drying, starch retrogradation, increased firmness and Fragility, as well as loss of aroma and flavor (Amigo, et al., 2016).

Staling results in the decrease of consumer acceptance for bakery products and in great economic losses challenges in the cake market include cost reduction, increased shelf life and quality control (Caballero, et al., 2007).

Use of enzymes, instead of chemical oxidants as a natural, non-toxic, specific biological catalysts able to react under mild conditions of temperature and $\mathrm{pH}$, to improve breadmaking performance of dough. (Sirbu and Paslaru, 2005).

Glucose oxidase (GO) (EC 1.1.3.4) is an oxidative enzyme that catalyzes the oxidation of $\beta$-d-glucose to $\delta$-d-gluconolactona and hydrogen peroxide. Disulfide bond interchange and the gelation of pentosans promoted by hydrogen peroxide action are the most widespread theories to explain the strengthening effect of the glucose oxidase. Furthermore, it has been related with the formation of non-disulfide covalent intermolecular bonds in the gluten proteins (Paucean et al., 2016).
Glucose oxidase is an oxidizing enzyme that has an effect similar to that of chemical oxidants: the improving of dough by increasing the resistance and decreasing the extensibility of the dough, the increasing of bread volume and the improving of crumb grain of bread. It appears that oxidation of water-soluble $\mathrm{SH}$ groups and the oxidative gelation of pentosans is the mechanism by which glucose oxidase improvers the rheological properties of the dough (Diaconescu, 2009).

$\alpha$-amylases (EC 3.2.1.1) are endo-acting amylases that hydrolyse $\alpha$-(1-4) glycosidic bonds of starch polymers, thereby resulting in oligosaccharides with varying lengths and $\alpha$-limit dextrins. Note that $\alpha$ amylase increases the amount of fermentable sugar and therefore enhances the yeast fermentation and the maillard reaction products, which, in turn, strengthen the flavor and color of bread (Sahnoun, et al., 2013). Additionally, $\alpha$-amylase increases the resistance, elasticity, and softness of the dough (Patel, et al., 2012) and decreases crumb firmness and hardness. However, it decreases dough extensibility and stability (Sahnoun, et al., 2016).

Generally, it can be concluded that bread with added $\alpha$-amylase presented an increase in volume and a reduction in firmness during storage, as well as good sensory acceptance. Further research could include the use of combined enzyme in other bakery products, including fiberenriched products, cakes, etc., where an increase in shelf-life is technologically and economically important (Gomes-Ruffi et al., 2012).

\author{
Materials And Methods \\ Materials: \\ Wheat flour (WF; 72\% extraction) Medium \\ Ukrainian wheat flour (Triticum aestvium L.) season \\ 2016 was obtained from Sanabel Mayo Golden Mills,
}


Giza, Egypt. $\alpha$-amylase obtained from sigma aldrich (USA), glucose oxidase was supplied from Chemtic Zyme company, Cairo, Egypt. Fresh egg, oil, sodium carbonate, vanilla, sugar, and milk were obtained from local market in Egypt.

\section{Methods:}

\section{English Cake formula :}

English cakes was prepared by mixing Ukrainian (72\% ext.) wheat flour $(760 \mathrm{~g})$, the corn oil $(380 \mathrm{~g})$ was beaten thoroughly, the sugar $(380 \mathrm{~g})$, fresh whole egg (380g), baking powder $(22.8 \mathrm{~g})$, skim powder milk $(26.6 \mathrm{~g})$, vanilla $(1 \mathrm{~g})$, water (based on farinograph absorption), enzymes as shown in Table (1), and mixed until got smooth like cream, and then a wellblended egg with vanilla were added and mixed together improvers as shown in Table (1), baking powder were stirred together and added alternately to the egg mixture. The mixture was whipped until got smooth. Then baked in an electric oven (Mac.pan Italy) at $200 \pm 5^{\circ} \mathrm{C}$ about the dough transferred to a greased pan and was baked for $25 \mathrm{~min}$. then was cooled at room temperature (A.A.C.C, 2002).

Table 1. Addition of Enzymes to $1000 \mathrm{~g}$ of Ukrainian wheat flour (72\% ext.) in production English cakes:

\begin{tabular}{cl}
\hline Treatment No. & Blends \\
\hline Control & Ukrainian wheat flour (without any additions). \\
\hline $\mathbf{1}$ & Ukrainian wheat flour $+0.3 \% \alpha$-amylase. \\
\hline $\mathbf{2}$ & Ukrainian wheat flour $+0.1 \%$ glucose oxidase .
\end{tabular}

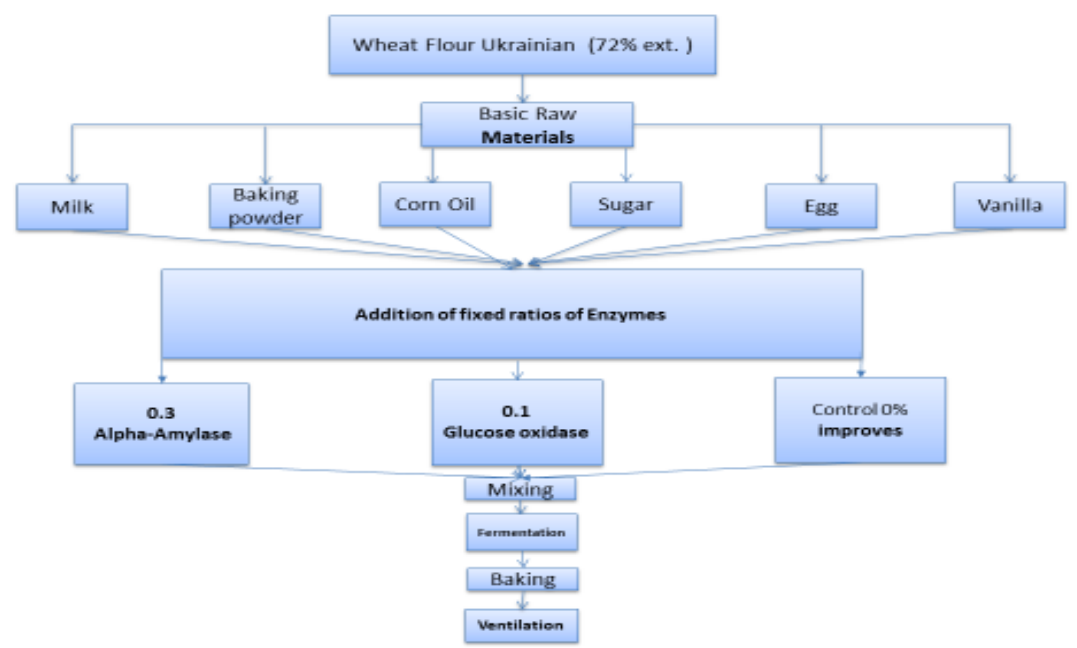

Fig (1). Processing of English cakes using different levels enzymes of Ukrainian wheat flour (72\% ext.)

\section{Chemical analysis:}

Moisture, protein, ash, crude fiber, ether extract, starch and reducing and non reducing sugars contents were determined according to the methods described in (AOAC, 2016) Total carbohydrates were calculated by difference.

\section{Rheological properties:}

\section{Farinograph test:}

The farinograph (877563 Brabender farinograph germany HZ 50) was used to study the hydration and mixing characteristics of the dough under investigation according to (A.A.C.C. 2002).

\section{Extensograph test:}

Extensograph test was carried out according to the method described in the (A.A.C.C. 2002) using an extensograph type: 4821384 (Brabender Extensograph Germany HZ 50).

Alveograph characteristics:
Alveograph test was carried out in an Alveograph MA 82 (Chopin, Tripetteet Renaud, France) following the approved method 54-30A (A.A.C.C, 2000).

\section{Mixolab test:}

Mixolab analysis was carried out at the water absorption level determined by the consistograph following the (A.A.C.C, 2000).

\section{Physical analysis of English cakes:}

\section{Texture measurements (mechanical properties) of English cakes:}

Mechanical properties of English cake and prepared with $\alpha$-amylase and glucose oxidase and stored at room temperature $\left(25 \pm 1^{\circ} \mathrm{C}\right)$ for 9 days mechanical properties measured at $0,3,9$ days were performed with a Universal Testing Machine Cometech (B type, Taiwan) operated at a crosshead speed of $100 \mathrm{~mm}$ min-1. The shear force needed to cut the sample $(5 \mathrm{~cm}$ diameter $)$ with a flat ended probe 
(2.5mm thickness) was registered. All measurements were performed at ambient temperature $\left(25 \pm 5^{\circ} \mathrm{C}\right)$ according to (Caballero et al., 2007).

\section{Determination of staling rate:}

Staling rate of the English Cakes were determined every $0,3,5,7,9$ and 12 days respectively, of storage at $25 \pm 1{ }^{\circ} \mathrm{C}$ (room temperature). by Alkaline water retention capacity (AWRC \%) as described by (Kitterman and Rubanthaler, 1971) as following:

AWRC $(\%)=[($ Weight of tube with sample after centrifuge - weight of empty tube)/Weight of sample] x 100.

\section{Microbiological examination:}

Preparation of samples for microbiological examination:

Ten grams of each sample were homogenized with $90 \mathrm{ml}$ of sterile saline solution $(9 \mathrm{~g} \mathrm{NaCL} / \mathrm{L}$ distilled water). The suspension was shacked by shaker for 5 minutes to give 0.1 dilutions. Then different dilutions (1: $10^{-1}$ to $\left.1: 10^{-6}\right)$ were prepared to be used for microbiological examination.

Total viable bacterial count, Moulds and yeasts and Coliform bacteria count:

Total viable bacterial count, Moulds and yeasts and Coliform bacteria count were counted according to the method described by the methodology of (APHA, 1992).

\section{Sensory evaluation of English cakes:}

English cake produced (control and different addition) was evaluated according to the method described by (A.A.C.C, 2002) A group of graduate students in food technology department faculty of agriculture, moshtohor-benha-university.

English cake samples were left to cool at room temperature for $1 \mathrm{hr}$. after baking. Then cake was cut with a sharp knife and subjected to panel test. textures (15), general appearance (15), taste (15), odor (15), sponge (10), crust color (10), crumb color (10), distribution of crumb (10), and overall acceptability was calculated (100).

\section{Statistical analysis:}

ANOVA was applied on data organoleptic evaluation, stalling and biological experimental of different samples of English cake which were treated as data for complete randomization design by using Microsoft Excel 2010 Least significant difference (L.S.D.) was calculated at 0.05 level of significance according. Levine et al., (1999).

\section{Results And Discussion}

4.1. Chemical composition of medium wheat flour:

Chemical composition of medium wheat flour Ukrainian is shown in Table (2). The results show that medium wheat flour contained $13.51 \%$ moisture, $12.01 \%$ protein, $0.74 \%$ fat, and $0.53 \%$ ash and 73.21 $\%$ total carbohydrates. Also, wet and dry gluten were $27.58 \%$ and $14.53 \%$, respectively.

There are many reasons that affect the protein content of wheat variety such as environmental conditions, agriculture operations and fertilizing all this after the influence of a gene (Dupont and Altenbach, 2003 and Sip et al., 2013). Also fat content is one of the most components that changing depending on the varieties and extraction. The carbohydrate content of the wheat flour was difference with different varieties. Carbohydrates are divided to fiber and available carbohydrates, which calculated by difference (El-Porai et al., 2013). Generally, we can see that the inverse relationship linearly between the carbohydrates and protein content.

These results of chemical composition of wheat flour are nearly are in agreement with the results reported by (El-sisy et al., 2014; ALtayeb et al., 2014; and Sahnoun et al., 2016) .

The chemical composition of Ukrainian wheat flour shown in Table (2) indicated that the flour was suitable to prepare good bakery products related to the percentage of protein and gluten. All the results indicated that the wheat flour generally represented medium strong flour.

Table 2. Chemical composition and some properties of Ukrainian wheat flour (72\% extraction).

\begin{tabular}{cccccccc}
\hline Components & Moisture & Ash & Protein & Fat & Carbohydrates & Wetgluten content & Dry gluten content \\
\hline WF72\% & 13.51 & 0.53 & 12.01 & 0.74 & 73.21 & 27.58 & 14.53 \\
\hline
\end{tabular}

\section{Rheological properties of Ukrainian wheat flour:}

Concerning dough rheology, it is well known that the farinograph parameters indicate the most important properties in this dough. The rheological properties of dough have an immediate impact on functionality of dough; therefore, it may be used as reliable predictors of its behavior during the baking process as well as the quality of the final product.

\subsection{Effect of addition some enzymes to Ukrainian wheat flour on rheological properties: \\ 4.3.1.Farinograph parameters:}

The farinograph is the most universally used for physical dough-testing instrument to measure the plasticity and mobility of the dough. It records the resistance dough offers to the mixing blends during a prolonged and relatively gentle mixing action at a constant temperature. 
The farinograph was used to study the hydration and mixing characteristics of that resultant dough under investigation. Three hundred grams of tested flour were placed in the bowel of the apparatus and sufficient water was added so that the consistency of the dough was such that the mixing curve was centered on the 500 Brabendar units (BU) line at the point of maximum development.

The farinograph characteristics of flour and flour containing different levels of enzymes in Table (3).

Water absorption of the control sample was the highest compared with other treatments was $57.1 \%$, while it was $55.6 \%$ for glucose oxidase, $\alpha$-amylase. Results in Table (3) It was also found that the addition of enzymes reduces the mixing time.
Of the results presented in the same table it can also be observed that the addition of enzymes Increase of the time of dough stability. The highest time in glucose oxidase was 8.0 and $4.0 \alpha$-amylase either sample the control was 2.5 . The increased stability time indicated the robustness of the flour and convenience of making cake.

The results of tolerance index take the same direction as time stability results. On the other hand, enzymes are not affected by the weakening of the dough. These results are consistent with those obtained by (El-Rashidy, 2015; Hassan at al,. 2015).

Dough weakening and degree of softening values were increased by treating wheat flour with $\alpha$-amylase (Inrani and Venkateseara Rao, 2006).

Table 3. Farinograph properties Ukrainian wheat flour with the addition of enzymes:

\begin{tabular}{lccccc}
\hline $\begin{array}{l}\text { Sample } \\
\text { (No.) }\end{array}$ & $\begin{array}{c}\text { Water } \\
\text { Absorption \% }\end{array}$ & $\begin{array}{c}\text { Arrival time } \\
(\mathbf{m i n})\end{array}$ & $\begin{array}{c}\text { Dough } \\
\text { Development(min) }\end{array}$ & $\begin{array}{c}\text { Stability time } \\
(\mathbf{m i n})\end{array}$ & $\begin{array}{c}\text { Degree of } \\
\text { softening(B.U) }\end{array}$ \\
\hline Control & 57.1 & 1.0 & 1.5 & 2.5 & 80 \\
\hline $\boldsymbol{\alpha}$-amylase & 54.7 & 1.0 & 2.0 & 4.0 & 130 \\
\hline Glucose oxidase & 55.6 & 1.0 & 1.5 & 8.0 & 60 \\
\hline
\end{tabular}

\subsubsection{Extensograph parameters:}

The results in Table (4) are shown effect of addition of enzymes at different levels to mean flour on extensograph parameters. Data indicate that resistance to control sample flexibility was 190 B.U. There are changes in elasticity with the addition of both enzymes to the intermediate flour. The elasticity was gradually increased with the addition of glucose oxidase increased flexibility to 300 B.U.It decreased from the addition of $\alpha$-amylase as it became 180 B.U.

The expansion (E) showed a value of $50 \mathrm{~mm}$ for control (Ukrainian wheat flour $72 \%$ XT.). The addition of $\alpha$-amylase was highest value was $120 \mathrm{~mm}$ As for glucose oxidase $55 \mathrm{~mm}$.

The relative number was dependent on the results of $(\mathrm{R})$ and $(\mathrm{E})$. Therefore, a similar relationship was found of the relative number $(\mathrm{R} / \mathrm{E})$ of the dough. The data in Table (4) also showed that the additions increased the relative number $(\mathrm{R} / \mathrm{E})$ of the dough and the glucose oxidase was 5.46 higher for control sample 3.80. These results are consistent with the results by (Bonet et al., 2006; and Steffolani $\boldsymbol{e t}$. al., 2010).

The data in Table (4) showed the effect of enzymes in the percentages of $\quad \alpha$-amylase and glucose oxidase \% with Ukrainian wheat flour (72\% extraction) on extensograph, (E), the extension resistance $(\mathrm{R})$ and the ratio between them as well as the energy.

In terms of energy, $\alpha$-amylase resulted in the highest value of 64 , while the control sample was the lowest value of 24 of the data mentioned in Table (4).

It can be concluded that the addition of enzymes was good for extensograph parameters.

Table 4. Extensograph properties of medium wheat flour Ukrainian with the addition of enzymes:

\begin{tabular}{ccccc}
\hline $\begin{array}{c}\text { Sample } \\
\text { (No.) }\end{array}$ & Elasticity (B.U) & $\begin{array}{c}\text { Extensibility } \\
(\mathbf{m m})\end{array}$ & $\begin{array}{c}\text { Proportional } \\
\text { number }\end{array}$ & Energy $\left(\mathbf{c m}^{2}\right)$ \\
\hline Control & 190 & 50 & 3.80 & 24 \\
\hline $\boldsymbol{\alpha}$-amylase & 180 & 120 & 1.50 & 64 \\
\hline Glucose oxidase & 300 & 55 & 5.46 & 30 \\
\hline
\end{tabular}

4.5.3. Effect of addition enzymes to medium Ukrainian wheat flour on rheological properties of dough on Mixolab parameters:

The results shown in Table (5) are shown the effect of addition enzymes at different levels. The mixolab curve is divided into five different stages in the first stage $(\mathrm{C} 1)$. The dough development values show a rise in the flour treatment with enzymes, which decreased slightly in the second phase (C2) and ranged from 0.35 to $0.41 \mathrm{Nm}$ compared with the torque value in the control sample is $0.45 \mathrm{Nm}$ These results are agreement with (Banu et al., 2008, and Szafranska, 2014).
The third phase (C3), which is called starch gluten at this stage and the product during heating from 1.92 $\mathrm{Nm}$ in the control sample to $2.12 \mathrm{Nm}$ in the sample of the Glucose oxidase the other $\alpha$-amylase was 1.67 Nm. According to (El-Rashidy, 2015).

In the first phase $(\mathrm{C} 1)$, the effect of enzymes was found on the values of dough development and Stage three (C3) in control sample and increased in all samples added to enzymes compared to a control sample. This results are in agreement with (Hassan et al., 2015; and Abd-Elrahman, 2016). 
Table 5. Effect of addition enzymes medium wheat flour on Mixolab characteristics:

\begin{tabular}{cccc}
\hline Simple & Control & $\boldsymbol{\alpha}$-amylase & Glucose oxidase \\
\hline Stability (min) & 9.82 & 4.50 & 4.33 \\
\hline Absorption & 1 & 1 & 2 \\
\hline Mixing & 2 & 1 & 1 \\
\hline Gluten+ & 6 & 3 & 6 \\
\hline Viscosity & 7 & 5 & 7 \\
\hline Amylase & 8 & 8 & 7 \\
\hline Retro gradation & 8 & 8 & 1.10 \\
\hline C1 $(\mathbf{N m})$ & 1.09 & 1.11 & 0.41 \\
\hline C2 $(\mathbf{N m})$ & 0.45 & 0.35 & 2.12 \\
\hline C3 $(\mathbf{N m})$ & 1.92 & 1.67 & 1.93 \\
\hline C4 $(\mathbf{N m})$ & 2.22 & 2.05 & 3.47
\end{tabular}

4.5.4 Effect of addition enzymes to Ukrainian wheat flour on rheological properties of dough on Alveograph parameters:

The results shown in Table (6) are shown the value of resistance $(\mathrm{P})$ showed a significant increase when dealing with flour enzymes where gave the highest value of the sample of glucose oxide $147 \mathrm{~mm}$, because glucose oxidase which increased covalent cross-linking among proteins markedly into the gluten network Compared to the control sample where it was $82 \mathrm{~mm}$ according to (Caballero et al., 2007, and Sahnoun et al., 2016).

The value of elasticity or elasticity (L) has been significantly increased by careful processing with the same concentration of enzymes where the value of elasticity or elasticity (L) was in the control sample 74 $\mathrm{mm}$, while $\alpha$-amylase were increased $91 \mathrm{~mm}$. This results are in agreement with Kriaa et al. (2016).
The resistance to elasticity $(\mathrm{P} / \mathrm{L})$ also increased with the use of enzymes, compared to the glucose oxidase sample where it was 5,65 these results are agreement with (El-Rashidy, 2015, and AbdElrahman, 2016).

In general, the treatment of flour with enzymes increased the value of resistance $(\mathrm{P})$, elasticity $(\mathrm{P} / \mathrm{L})$ and elasticity (L), This results are in agreement with Paucean et al., (2016).

The study concluded that the flour became suitable for the bakery product industry and gave very excellent characteristics of the bakery product compared to the control sample of English cake.

The value of rubber $(\mathrm{L})$ is significantly increased by careful processing with enzymes except for the sample of glucose oxidase. Thus, the samples suitable for baking.

Table 6. Effect of addition enzymes to Ukrainian wheat flour on Alveograph characteristics:

\begin{tabular}{ccccccc}
\hline $\begin{array}{c}\text { Sample } \\
\text { (No.) }\end{array}$ & $\mathbf{P}(\mathbf{m m})$ & $\mathbf{L}(\mathbf{m m})$ & $\mathbf{( P / L}$ Ratio) & $\mathbf{G}$ & $\mathbf{W}$ & Le\% \\
\hline Control & 82 & 74 & 1,11 & 19,1 & 220 & 59,5 \\
\hline $\boldsymbol{\alpha}$-amylase & 65 & 91 & 0,71 & 21,2 & 277 & 60,7 \\
\hline Glucose oxidase & 147 & 26 & 5,65 & 11,3 & 183 & 72,1 \\
\hline
\end{tabular}

\subsection{The effect of the addition of Enzymes to improvers the characteristics of English cake product:}

In this part of the study we will study the effect of the addition of selected enzymes: $\alpha$ - amylase by add ratio $0.3 \%$, glucose oxidase by add ratio 0.1 to English cake and study all the quality characteristics: chemical, microbiological, and sensory of English cake and finally measure freshness of the product .

Chemical composition is great importance in judging the quality of the English cake product. Therefore, the chemical composition of English cake mead by adding the enzymes and were determined, moisture, ash, protein, fat and carbohydrate of the product at the beginning of manufacturing and after storage for the following zero time, 3,5,7, 9 and 12 days at $25 \pm 1^{\circ} \mathrm{C}$.

\subsubsection{Effect of Enzymes to improvers the chemical composition of English Cake during storage at $25 \pm 1^{\circ} \mathrm{C}$ :}

Chemical composition is great importance in judging the quality of the cake product. Therefore, the chemical composition of English cake mead by adding the enzymes and were determined, moisture, ash, protein, fat and carbohydrate of the product at the beginning of manufacturing and after storage for the following $0,3,5,7,9$ and 12 days at $25 \pm 1^{\circ} \mathrm{C}$ and the date were showed in the Table (7).

The results chemical composition in Table (7) showed that The control sample was the least of the samples in the moisture content of from the enzymes because of its retention of water as on the contrary to the control sample. These results are consistent with (Sharoba et al. 2013). 
The additives were ineffective in ash content, while if a decrease or increase was due to decrease or increase of other components such as moisture. These results are in agreement with (Hassan 2010).

For the protein content the glucose oxidase and $\alpha$ amylase sample had the highest percentage of the control samples and the percentage of protein in the glucose oxidase sample at the beginning of the manufacturing $11.83 \%$ to the 9 day was $9.82 \%$ and the $\alpha$-amylase sample were ranged between $11.81 \%$ to the 12 day was $9.64 \%$ and the control sample at the beginning of the manufacturing $11.30 \%$ to the 7 day was $9.37 \%$ during storage. This results are in agreement with (Schmiele et al., 2012).

On the other hand, the fat values were had a Decreased during storage. The result of the samples during storage period for 12 days. It was observed that there was an decreased the all samples for example control sample ranged between $16.06 \%$ to $13.39 \%$ and the $\alpha$-amylase sample ranged between $16.24 \%$ to $13.79 \%$ and the glucose oxidase sample ranged between $16.18 \%$ to $13.13 \%$. This results are in agreement with (Sharoba et al., 2005 and AbdElrahman, 2016).

Table 7. Effect of the chemical composition of English cake addition levels of enzymes and chemicals improvers during storage at $25 \pm 1^{\circ} \mathrm{C}$ for 12 days:

\begin{tabular}{|c|c|c|c|c|c|c|c|}
\hline \multirow{2}{*}{$\begin{array}{l}\text { Chemical } \\
\text { attributes }\end{array}$} & \multirow{2}{*}{ Blends } & \multicolumn{6}{|c|}{ Storage } \\
\hline & & Zero time & 3 Days & 5 Days & 7 Days & 9 Days & 12 Days \\
\hline \multirow{4}{*}{ 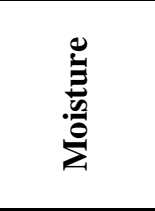 } & Control & 26.97 & 23.49 & 21.12 & 19.58 & Rejected & Rejected \\
\hline & $\alpha$-amylase & 24.12 & 24.02 & 23.86 & 21.32 & 20.01 & 18.71 \\
\hline & $\begin{array}{l}\text { Glucose } \\
\text { oxidase }\end{array}$ & 24.34 & 24.13 & 23.43 & 21.15 & 19.61 & Rejected \\
\hline & Average & 25.14 & 23.88 & 22.80 & 20.68 & 19.81 & 18.71 \\
\hline \multirow{4}{*}{$\frac{5}{4}$} & Control & 1.05 & 1.11 & 1.23 & 1.29 & Rejected & Rejected \\
\hline & $\alpha$-amylase & 1.19 & 1.24 & 1.26 & 1.31 & 1.38 & 1.26 \\
\hline & $\begin{array}{l}\text { Glucose } \\
\text { oxidase }\end{array}$ & 1.16 & 1.17 & 1.26 & 1.33 & 1.39 & Rejected \\
\hline & Average & 1.13 & 1.17 & 1.25 & 1.31 & 1.39 & 1.26 \\
\hline \multirow{4}{*}{ 竞 } & Control & 11.30 & 10.05 & 9.48 & 9.37 & Rejected & Rejected \\
\hline & $\alpha$-amylase & 11.81 & 10.53 & 10.42 & 10.13 & 9.83 & 9.64 \\
\hline & $\begin{array}{l}\text { Glucose } \\
\text { oxidase }\end{array}$ & 11.83 & 10.60 & 10.37 & 10.12 & 9.82 & Rejected \\
\hline & Average & 11.65 & 10.39 & 10.09 & 9.87 & 9.83 & 9.64 \\
\hline \multirow{4}{*}{$\underset{\mid \vec{x}}{\vec{\sigma}}$} & Control & 16.06 & 15.46 & 15.06 & 13.39 & Rejected & Rejected \\
\hline & $\alpha$-amylase & 16.24 & 15.57 & 15.14 & 14.84 & 14.25 & 13.79 \\
\hline & $\begin{array}{l}\text { Glucose } \\
\text { oxidase }\end{array}$ & 16.18 & 15.54 & 14.73 & 13.96 & 13.13 & Rejected \\
\hline & Average & 16.16 & 15.52 & 14.98 & 14.06 & 13.69 & 13.79 \\
\hline \multirow{4}{*}{ 章 } & Control & 44.62 & 49.89 & 53.11 & 56.37 & Rejected & Rejected \\
\hline & $\alpha$-amylase & 46.64 & 48.64 & 49.32 & 52.40 & 54.53 & 56.60 \\
\hline & $\begin{array}{l}\text { Glucose } \\
\text { oxidase }\end{array}$ & 46.49 & 48.56 & 50.21 & 53.44 & 56.05 & Rejected \\
\hline & Average & 45.92 & 49.03 & 50.88 & 54.07 & 55.29 & 56.60 \\
\hline
\end{tabular}

4.6.2. Effect of enzymes improvers in the microbiological properties of English cake during storage at $25 \pm 1^{\circ} \mathrm{C}$ :

The total viable bacterial count is widely used as an indicator microbiological quality of English cake. Data in Table (8) indicated that, the total viable bacterial count was detected in few numbers and this result was under Iraqi and Egyptian standard specification. Molds and Yeast cannot be detected, this may that yeast and Mold cannot resist for drying. Coliform group were not detected. This results are in agreement with (Gupta et al., 2003; and Sahnoun et al., 2016). 
Table 8. Microbiological quality of English cake included enzymes (CFU/g).

\begin{tabular}{|c|c|c|c|c|}
\hline Sample & Time & T. C & Mold and Yeast & Coliform group \\
\hline Control & \multirow{3}{*}{ हृ } & $6.2 \times 10$ & N D* & $\mathbf{N ~ D * *}$ \\
\hline$\alpha$-amylase & & $4.1 \times 10$ & N D & N D \\
\hline Glucose oxidase & & $4.8 \times 10$ & N D & N D \\
\hline Control & \multirow{3}{*}{ in } & $6.1 \times 10^{2}$ & $5.3 \times 10$ & N D \\
\hline$\alpha$-amylase & & $3.7 \times 10^{2}$ & $2.1 \times 10$ & N D \\
\hline Glucose oxidase & & $4.2 \times 10^{2}$ & $2.5 \times 10$ & N D \\
\hline Control & \multirow{3}{*}{ a } & $7.7 \times 10^{2}$ & $4.9 \times 10^{2}$ & N D \\
\hline$\alpha$-amylase & & $3.8 \times 10^{2}$ & $2.6 \times 10^{2}$ & N D \\
\hline Glucose oxidase & & $5.5 \times 10^{2}$ & $3.4 \times 10^{2}$ & N D \\
\hline Control & \multirow{3}{*}{ 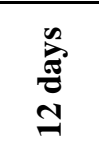 } & $7.6 \times 10^{3}$ & $7.7 \times 10^{2}$ & N D \\
\hline$\alpha$-amylase & & $3.0 \times 10^{3}$ & $5.1 \times 10^{2}$ & N D \\
\hline Glucose oxidase & & $4.4 \times 10^{3}$ & $4.9 \times 10^{2}$ & N D \\
\hline
\end{tabular}

* ND: not detect.

** Less than standard count.

\subsubsection{Use Sensory evaluation of English cake with addition enzymes:}

Sensory evaluation is important criteria in evaluating English cake quality.

The sensory evaluation of English cake was evaluated 12 trained sensory panelists evaluated the samples. All additions of $\alpha$-amylase, and glucose oxidase on of Ukrainian wheat flour (72\% ext.).

Data in Table (9) indicated that there are significant differences $(\mathrm{p} \leq 0.05)$ between all enzymes. The obtained data indicated that of enzymes are giving marked $(\mathrm{p} \leq 0.05)$ improvement in all attributes compared with control.
Addition of $\alpha$-amylase, and glucose oxidase by difference addition showed improving of all attributes with treatment when compared with control were low improving, these results agree dramatically with (sharoba, 2013; El-Rashidy, 2015; and AbdElrahman, 2016).

while some other attributes shown a clear contrast between treatments such as textures and overall acceptability which stressed the advantage both of $\alpha$ amylase, and glucose oxidase treatment. The value of the overall acceptability in the control sample $79 \%, \alpha-$ amylase sample $92.7 \%$, glucose oxidase sample $90 \%$.

Table 9. Sensory evaluation of English cake with addition enzymes:

\begin{tabular}{|c|c|c|c|c|c|c|c|c|c|}
\hline \multirow[b]{2}{*}{$\begin{array}{c}\text { Sample } \\
\text { s No }\end{array}$} & \multicolumn{9}{|c|}{ Characteristics } \\
\hline & $\begin{array}{c}\text { Texture } \\
\text { s (15) }\end{array}$ & $\begin{array}{c}\text { General } \\
\text { appearanc } \\
\text { e (15) }\end{array}$ & $\begin{array}{c}\text { Taste } \\
\text { (15) }\end{array}$ & $\begin{array}{c}\text { Odor } \\
(15)\end{array}$ & $\begin{array}{l}\text { Spong } \\
\text { e (10) }\end{array}$ & $\begin{array}{c}\text { Crust } \\
\text { color } \\
(\mathbf{1 0})\end{array}$ & $\begin{array}{c}\text { Crum } \\
\text { b } \\
\text { color } \\
(10)\end{array}$ & $\begin{array}{c}\text { Distributio } \\
\text { n of crumb } \\
\text { (10) }\end{array}$ & $\begin{array}{c}\text { Overall } \\
\text { acceptabilit } \\
\text { y (100) }\end{array}$ \\
\hline Control & $\begin{array}{l}12.10^{\mathbf{b}} \\
\pm 0.448\end{array}$ & $\begin{array}{l}13.10^{\mathrm{a}} \\
\pm 0.407\end{array}$ & $\begin{array}{c}11.20 \\
\mathbf{b} \\
\pm 0.35 \\
9\end{array}$ & $\begin{array}{c}12.10 \\
\mathbf{b} \\
\pm 0.69 \\
0\end{array}$ & $\begin{array}{c}8.20^{\mathbf{b}} \\
\pm 0.249\end{array}$ & $\begin{array}{c}8.20^{\mathrm{a}} \\
\pm 0.29 \\
1\end{array}$ & $\begin{array}{c}7.90^{\mathrm{a}} \\
\pm 0.277\end{array}$ & $\begin{array}{c}8.20^{\mathbf{b}} \\
\pm 0.249\end{array}$ & $\begin{array}{l}79.00^{\mathbf{b}} \\
\pm 2.139\end{array}$ \\
\hline $\begin{array}{c}\alpha- \\
\text { amylase }\end{array}$ & $\begin{array}{l}13.90^{\mathrm{a}} \\
\pm 0.433\end{array}$ & $\begin{array}{l}14.10^{\mathrm{a}} \\
\pm 0.314\end{array}$ & $\begin{array}{c}13.90 \\
\mathbf{a} \\
\pm 0.37 \\
9\end{array}$ & $\begin{array}{l}14.30 \\
\quad \mathbf{a} \\
\pm 213\end{array}$ & $\begin{array}{l}9.80^{\mathrm{a}} \\
\pm 0.2\end{array}$ & $\begin{array}{c}9.60^{\mathrm{a}} \\
\pm 0.16 \\
3\end{array}$ & $\begin{array}{c}9.10^{\mathrm{a}} \\
\pm 0.277\end{array}$ & $\begin{array}{l}9.90^{a} \\
\pm 0.1\end{array}$ & $\begin{array}{l}92.70^{\mathrm{a}} \\
\pm 1.350\end{array}$ \\
\hline $\begin{array}{l}\text { Glucose } \\
\text { oxidase }\end{array}$ & $\begin{array}{c}14.00^{\mathrm{a}} \\
\pm 0.258\end{array}$ & $\begin{array}{l}13.80^{\mathrm{a}} \\
\pm 0.291\end{array}$ & $\begin{array}{c}13.30 \\
\mathbf{a} \\
\pm 0.44 \\
8\end{array}$ & $\begin{array}{c}13.80 \\
\mathbf{a b} \\
\pm 0.29 \\
1\end{array}$ & $\begin{array}{c}9.70^{\mathrm{a}} \\
\pm 0.153\end{array}$ & $\begin{array}{c}8.90^{\mathrm{a}} \\
\pm 0.27 \\
7\end{array}$ & $\begin{array}{c}9.10^{\mathrm{a}} \\
\pm 0.233\end{array}$ & $\begin{array}{l}8.60^{\text {ab }} \\
\pm 0.267\end{array}$ & $\begin{array}{l}90.00^{\mathrm{a}} \\
\pm 1.921\end{array}$ \\
\hline LSD & 1.624 & 1.009 & $1.74 \varepsilon$ & 1.211 & 1.210 & $1.50 \mathrm{~V}$ & 1.579 & $1 . \Sigma Y V$ & $\varepsilon .091$ \\
\hline
\end{tabular}

4. \. . Effect of addition enzymes on texture measurement (mechanical properties) of English Cake storage for different time.

Data listed in Table (10) showed the $\alpha$-amylase and glucose oxidase initially presented very similar hardness values to each other, even lower than those for the control.In these samples the hardness values also increased with storage time,ndicating that the crumb develops far less firmness over time and demonstrating the effectiveness of the enzymes in maintaining freshness. These results are in agreement with (Caballero et al., 2007). 
springiness Increased when you add of glucose oxidase English cakes while the control sample decreased.

A subjective evaluation of springiness is normally made by consumers and consists of slightly pressing the piece of food, by hand or with the mouth, and verifying how easily it returns to the original size. Regarding springiness change during storage in Table (10), a decrease was observed during ageing.

The 'cohesiveness' value of the control sample at (0) days was much lower than that of all the samples prepared with enzymes and fell significantly with storage time, indicating a tendency to present a crumblier or less cohesive structure.showing an ageing pattern more similar to that of the control bread. These results are in agreement with Kriaa et al. (2016).

The above results indicate that addition of enzyme, glucose oxidase is beneficial in improving the texture. According to (Fiszman et al., 2005).

Table 10. Effect of addition enzymes on texture measurement (mechanical properties) of English cake storage at $25 \pm 1^{\circ} \mathrm{C}$ :

\begin{tabular}{|c|c|c|c|c|c|c|}
\hline Sample (No.) & & Hardness & Springiness & Cohesiveness & Gumminess & Chewiness \\
\hline Control & \multirow{3}{*}{ 항 } & 8.76 & 1.86 & 1.11 & 11.44 & 21.30 \\
\hline$\alpha$-amylase & & 8.51 & 1.74 & 1.22 & 10.60 & 18.40 \\
\hline Glucose oxidase & & 8.43 & 2.39 & 1.17 & 14.56 & 34.80 \\
\hline Average & & 8.57 & 2.00 & 1.17 & 12.20 & 24.83 \\
\hline Control & \multirow{3}{*}{ 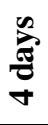 } & 18.36 & 6.30 & 0.44 & 8.05 & 50.70 \\
\hline$\alpha$-amylase & & 20.80 & 7.00 & 0.49 & 10.10 & 70.70 \\
\hline Glucose oxidase & & 23.99 & 9.15 & 0.57 & 13.66 & 125.00 \\
\hline Average & & 21.05 & 7.48 & 0.50 & 10.60 & 82.13 \\
\hline Control & \multirow{3}{*}{$\sum_{0}^{0}$} & 16.06 & 2.03 & 0.93 & 14.96 & 30.40 \\
\hline$\alpha$-amylase & & 14.89 & 2.16 & 0.93 & 13.85 & 29.90 \\
\hline Glucose oxidase & & 17.67 & 2.41 & 0.99 & 17.45 & 42.00 \\
\hline Average & & 16.21 & 2.20 & 0.95 & 15.42 & 34.10 \\
\hline Average & & 15.28 & 3.89 & 0.87 & 12.74 & 47.02 \\
\hline
\end{tabular}

4.6.5. Effect of enzymes improvers in the staling of English cake during storage at $25 \pm 1^{\circ} \mathrm{C}$ :

Staling it is a challenge for bakery products to improve dough properties and retard or delay staling property to keep bread quality high as long as possible. Staling includes all processes that occur in both crumb and crust during storage.

The crust becomes soft and leathery due to diffusion of water from the crumb to the crust. They also found that, amylopectin recrystallization is still believed to be the major cause of bread staling. There for we used some enzymes to control the staling bakery products and increase the shelf life of bread.

The results showed in the Table (11) that the highest values in staling were done in the control sample. The staling values were on the 0 day 1.79 and it became on the 7 day in which rejected 1.29 , while the staling was lower in the $\alpha$-amylase sample 1.43 at 0 day and became 0.93 in the 12 day then followed by a sample glucose oxidase sample 1.60 at 0 day and became 1.06 in the 9 day according to (Amigo et al., 2016).

Table 11. Effect addition Enzymes improvers staling of storage english cake at $25 \pm 1^{\circ} \mathrm{C}$ :

\begin{tabular}{lcccccc} 
Simple & $\mathbf{0}$ day & $\mathbf{3}$ day & $\mathbf{5}$ day & $\mathbf{7}$ day & $\mathbf{9}$ day & $\mathbf{1 2}$ day \\
\hline Control & 1.79 & 1.53 & 1.47 & 1.29 & Rejected & Rejected \\
\hline $\boldsymbol{\alpha}$-amylase & 1.43 & 1.30 & 1.21 & 1.19 & 1.12 & $\mathbf{0 . 9 3}$ \\
\hline Glucose oxidase & 1.60 & 1.39 & 1.19 & 1.11 & 1.06 & Rejected \\
\hline Average & $\mathbf{1 . 6 1}$ & $\mathbf{1 . 4 1}$ & $\mathbf{1 . 2 9}$ & $\mathbf{1 . 2 0}$ & $\mathbf{1 . 0 9}$ & $\mathbf{0 . 9 3}$ \\
\hline
\end{tabular}

\section{The Conclusions:}

The supplementation of the Ukrainian flour (extract $72 \%$ ) showed a significant improvement each of the properties. Specific volume has increased with every treatment, though it the $\alpha$-amylase treatment was a highly effective. But the glucose oxidase treatment was a lower effective. Alkaline water retention capacity,improved with add all of the treatments. Despite the contrast level of improvement between different enzymes. Add enzymes showed a noticeable positive change in the rheologicale properties. All of these changes culminated in the sensory evaluation, which showed a significant approbation for treatments compared with the control sample. 


\section{References}

1. Patel, M. J., Ng, J. H. Y., Hawkins, W. E., Pitts, K. F., and Chakrabarti-Bell, S. (2012). Effects of fungal $\alpha$-amylase on chemically leavened wheat flour doughs. Journal of cereal science, 56(3), 644-651.

2. A.A.C.C. (2000). American Association for Cereal chemistry. 10th Edition. AACC international, St. Paul. MN.

3. A.A.C.C. (2002): Approved Method of American Association of Cereal Chemists, published by American Association of Cereal Chemists, Ins. St. Paul, Minnesota, USA.

4. A.O.A.C. (2016): Association of Official Analytical Chemists. Official Methods of Analysis. $\left(20^{\text {th }}\right.$ Ed.) Maryland, USA.

5. Abd-Elrahman, M. G. M. (2016). USING OF SOME ENZYMES TO IMPROVE QUALITY OF SOME BAKRY PRODUCTS. B.Sc. Agric. Sci. (Food Science), Fac. of Agric., Benha University.

6. Abd-Elrahman, M. G. M. (2016). Using of Some Enzymes to Improve Quality of Some Bakery Products. B.Sc. Agric. Sci. (Food Science), Fac. of Agric., Benha University.

7. ALtayeb, A. A., Abdalla, A. A., and Briema, A. A. (2014). Chemical Composition, Falling Number and Gluten Quality of Three Commercial Wheat Brands. University of Kordofan Journal of Natural Resources and Environmental Studies, 1(1), 54-59.

8. American Public Health Association (APHA) (1992). Compendium of Method for the Microbiological Examination of Food. Washington.

9. Amigo, J. M., del Olmo Alvarez, A., Engelsen, M. M., Lundkvist, H., and Engelsen, S. B. (2016). Staling of white wheat bread crumb and effect of maltogenic $\alpha$-amylases. Part 1: Spatial distribution and kinetic modeling of hardness and resilience. Food chemistry, 208, 318-325.

10. Amigo, J. M., del Olmo Alvarez, A., Engelsen, M. M., Lundkvist, H., and Engelsen, S. B. (2016). Staling of white wheat bread crumb and effect of maltogenic $\alpha$-amylases. Part 1: Spatial distribution and kinetic modeling of hardness and resilience. Food chemistry, 208, 318-325.

11. Banu, I., Stoenescu, G., \& Ionescu, V. (2008). Improvement of dough rheology and bread quality by enzymes combination. Bulletin of University of Agricultural Sciences and Veterinary Medicine Cluj-Napoca. Agriculture, 65(2).

12. Bonet, A.; Rosell, C.M.; Caballero, P.A.; Go'mez, M.; Pe'rez-Munuera, I. and Lluch, M.A. (2006): Glucose oxidase effect on dough rheology and bread quality: A study from macroscopic to molecular level. Food Chemistry 99 (2006) 408-415.

13. Caballero, P. A., Gomez, M., and Rosell, C. M. (2007). Improvement of dough rheology, bread quality and bread shelf-life by enzymes combination. Journal of food engineering, 81(1), 42-53.

14. Caballero, P. A., Gomez, M., and Rosell, C. M. (2007). Improvement of dough rheology, bread quality and bread shelf-life by enzymes combination. Journal of food engineering, 81(1), 42-53.

15. Diaconescu, D. (2009). The Glucose Oxidase Using in Breadmaking Biotechnology. Revista de Chimie, 60. (5): 454-457.

16. Dupont, F.M. and Altenbach, S.B. (2003). Molecular and biochemical impacts of environmental factors on wheat grain development and protein synthesis. Journal of Cereal Science, 38(2): 133-146.

17. EL Rashidy, L. A. F. (2015). USING OF SOME ENZYMES TO IMPROVE THE QUALITY OF SOME BAKERY PRODUCTS. Food Science Department Faculty of Agriculture, Benha University.

18. El-Porai, E.; Salama, A.; Sharaf, A.; Hegazy, A. and Gadallah, M. (2013). Effect of different milling processes on Egyptian wheat flour properties and pan bread quality. Annals of Agricultural Sciences, 58(1): 51-59.

19. El-sisy, T.T., Jehan, B. Ali and Masoud M.S. (2014). Effect of Using Sorghum On the Quality of Wheat Mixtures and Their Flour. J. Food and Dairy Sci., Mansoura Univ., Vol. 5 (12): 919 - 942, 2014.

20. Fiszman, S. M., Salvador, A., and Varela, P. (2005). Methodological developments in bread staling assessment: application to enzymesupplemented brown pan bread. European Food Research and Technology, 221(5), 616-623.

21. Gomes-Ruffi, C. R., da Cunha, R. H., Almeida, E. L., Chang, Y. K., and Steel, C. J. (2012). Effect of the emulsifier sodium stearoyl lactylate and of the enzyme maltogenic amylase on the quality of pan bread during storage. LWT-Food Science and Technology, 49(1), 96-101.

22. Gupta, R., Gigras, P., Mohapatra, H., Goswami, V. K., and Chauhan, B. (2003). Microbial $\alpha$-amylases: a biotechnological perspective. Process biochemistry, 38(11), 15991616.

23. Hafez, A. A. (2012). Physico-chemical and sensory properties of cakes supplemented with different concentration of marjoram. Australian Journal of Basic and Applied Sciences, 6(13), 463470.

24.Hassan, A.A.; Mansour, E.H.; El Bedawey, A. E.F. A. and Zaki, M.S. (2015). Effect of $\alpha$ amylase enzyme on rheological properties and quality of Betifore-type cookies. Biolife, 3(1): 3139.

25. Hassan, A.A.M. (2010). Improvement of the quality of some food doughs by using some food 
additives. Ph.D. Theses, Faculty of Agriculture. Minufiya University.

26. Indrani, D., and Venkateswara Rao, G. (2006). Effect of additives on rheological characteristics and quality of wheat flour parotta. Journal of texture studies, 37(3), 315-338.

27. Indrani, D., Soumya, C., Rajiv, J., and Venkateswara Rao, G. (2010). Multigrain breadits dough rheology, microstructure, quality and nutritional characteristics. Journal of texture studies, 41(3), 302-319.

28. Kitterman, J. and Rubenthaler, G. (1971). Application of the Brookfield viscometer for measuring the apparent viscosity of acidulated flour-water suspensions. Cereal Science Today,275-276.

29. Kriaa, M., Ouhibi, R., Graba, H., Besbes, S., Jardak, M., and Kammoun, R. (2016). Synergistic effect of Aspergillus tubingensis CTM 507 glucose oxidase in presence of ascorbic acid and $\alpha$-amylase on dough properties, baking quality and shelf life of bread. Journal of food science and technology, 53(2), 1259-1268.

30. Levine, D. M., Berenson, M. L., and Stephan, D. (1999). Statistics for managers using Microsoft Excel (Vol. 660). Upper Saddle River, NJ: Prentice Hall.

31. Paucean, A., MAN, S., and SOCACI, S. A. (2016). WHEAT GERM BREAD QUALITY AND DOUGH RHEOLOGY AS INFLUENCED BY ADDED ENZYMES AND ASCORBIC ACID. Studia Universitatis Babes-Bolyai, Chemia, 61(2).

32. Sahnoun, M., Kriaa, M., Besbes, S., Jardak, M., Bejar, S., and Kammoun, R. (2016). Optimization of Aspergillus oryzae S2 $\alpha$-amylase, ascorbic acid, and glucose oxidase combination for improved French and composite Ukrainian wheat dough properties and bread quality using a mixture design approach. Food Science and Biotechnology, 25(5), 1291-1298.

33. Sahnoun, M., Naili, B., Elgharbi, F., Kammoun, R., Gabsi, K., and Bejar, S. (2013). Effect of Aspergillus oryzae CBS $819.72 \alpha$-amylase on rheological dough properties and bread quality. Biologia, 68(5), 808-815.

34. Schmiele, M., Jaekel, L. Z., Patricio, S. M. C., Steel, C. J., and Chang, Y. K. (2012). Rheological properties of wheat flour and quality characteristics of pan bread as modified by partial additions of wheat bran or whole grain wheat flour. International journal of food science and technology, 47(10), 2141-2150.

35. Sharoba, A. M., Farrag, M. A., and Abd ElSalam, A. M. (2013). Utilization of some fruits and vegetables waste as a source of dietary fiber and its effect on the cake making and its quality attributes. Journal of Agroalimentary Processes and Technologies, 19(4), 429-444.

36. Sharoba, A. M., Senge, B., El-Mansy, H. A., Bahlol, H. E., and Blochwitz, R. (2005). Chemical, sensory and rheological properties of some commercial German and Egyptian tomato ketchups. European Food Research and Technology, 220(2), 142-151.

37.Sip, V.; Vavera, R.; Chrpova, J.; Kusa, H. and Ruzek, P. (2013). Winter wheat yield and quality related to tillage practice, input level and environmental conditions. Soil and Tillage Research, 132: 77-85.

38. Sirbu, A. and Pâslaru, V. (2005). Influence of Lipase Products On Technological Properties Of The Bread Flour. Scientifical Researches. Agroalimentary Processes and Technologies, Volume XI, No. 1 (2005), 185-192.

39. Steffolani, M. E., Ribotta, P. D., Pérez, G. T., and León, A. E. (2010). Effect of glucose oxidase, transglutaminase, and pentosanase on wheat proteins: Relationship with dough properties and bread-making quality. Journal of cereal science, 51(3), 366-373.

40. Szafranska, A. (2014). Comparison of alphaamylase activity of wheat flour estimated by traditional and modern techniques. Acta Agrophysica, 21(4).

41. Yang, T., Bai, Y., Wu, F., Yang, N., Zhang, Y., Bashari, M., ... and Xu, X. (2014). Combined effects of glucose oxidase, papain and xylanase on browning inhibition and characteristics of fresh whole wheat dough. Journal of Cereal Science, 60(1), 249-254

42. Zhang, Y. Y., Song, Y., Hu, X. S., Liao, X. J., Ni, Y. Y., and Li, Q. H. (2012). Effects of sugars in batter formula and baking conditions on 5hydroxymethylfurfural and furfural formation in sponge cake models. Food research international, 49(1), 439-445. 


\section{تحسين صفات الجودة على منتج الكيك الانجليزي باستخدام بعض الانزيمات

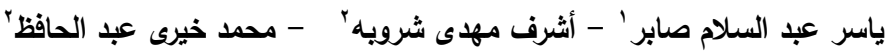 'قسم علوم الأغذية -كلية الزراعة -جامعة تكريت -العراق

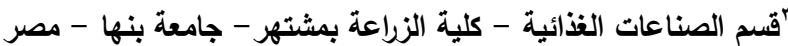

تحنل منتجات المخابز مكانة هامة في تغذية الانسان محلياً وعالمباً. ونظراً لوجود فجوة قحية بين الإنتاج والاستهلاك تلجأ الحكومات الى استيراد الاقماح من دول مختلفة. لذلك يعتبر القمح الاوكراني من أكثر الاقماح استخداماً في مصر والعراق. وذللك لتمانل خصائصها مع الاقماح

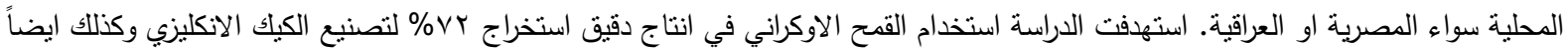

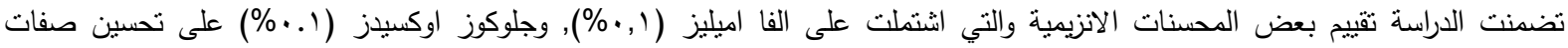
وخصائص بعض الكيك الانجليزي. كما تضمنت الدراسة التعرف على خصائص الكيك الانكليزي من حيث (التركيب الكيمياوي - الجلوتين -

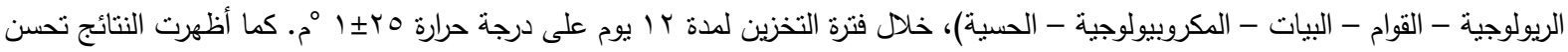
واضح وملحوظ لجميع الصفات التكنولوجية تحت الدراسة وكانت أهمها زيادة مدة الصلاحية لتصل لمدة rا بوم للكيلك الإنكليزي مقارنة بعينة (الكونترول). لذلك نوصي الدراسة باستخدام المحسنات النالية الفا اميليز ، جلوكوز اوكسيدزعلى النطاق التجاري في تصنيع بعض منتجات المخابز . 
